Vol. 52, no. 1 (2014), pp. 149-174, doi: 10.14421/ajis.2014.521.149-174

\title{
BEING A MUSLIM IN ANIMISTIC WAYS
}

\section{Samsul Maarif}

Center for Religious and Cross-cultural Studies (CRCS) Graduate School, Yogyakarta, Indonesia

email:anchu75@yahoo.com

\section{Abstract}

This paper examines religious practices of Ammatoans professed to be "Islamic" by practitioners, but ethnocentrically understood as "animistic" in Tylorian sense by scholars. Scholars have argued that Ammatoans' practices are incompatible with Islam. Islam and animism are mutually exclusive. This paper, in contrast, argues that Islam and animism are all encompassing. To build the argument, this paper firstly elaborates scholars' revisited theory of animism that argues for the (indigenous) notion of personhood as not limited only to buman beings, but extended to non-buman beings: land, forest, trees, animals and so forth. Secondly, this paper reviews the Quranic verses that explicate the personhood of non-buman beings, and finally Ammatoans' practices -visits to forest, refusal of electricity installation and others-as ethically responsible and mutually beneficial acts that ensure the well-beings of both human and non-human beings (interpersonal relations). These presentations show how Ammatoans exemplify being Muslim in animistic ways.

[Artikel ini membahas praktik keagamaan masyarakat Ammatoa, yang menurut pelakunya disebut "Islamic", tetapi menurut abli etnografi sering disebut animistik, karena tidak sesuai dengan ajaran Islam. Islam dan animisme saling menafikan. Namun hasil penelitian ini membuktikan lain, Islam and animisme saling terkait dan saling mengisi. Untuk mengawali pembahasan, dipaparkan pandangan para abli mengenai konsep "baru" anismisme yang memandang konsep dasar tentang diri tidak. banya terbatas pada manusia, tetapi juga mencakup selain manusia: tanah, butan, pohon, bewan, dan lain-lain. Ayat-ayat al-Quran juga memperkenalkan adanya 
konsep diri bagi selain manusia. Baru kemudian dibahas mengenai praktikpraktik masyarakat Amatoa, seperti masuk, butan, menolak instalasi listrik, dan lainnya, yang merupakan tanggung jawab moral serta bermanfaat bagi kehidupan, baik bagi manusia maupun selain manusia dalam konteks bubungan interpersonal. Paparan ini menunjukkan corak, khas masyarakat Ammatoa untuke menjadi seorang muslim dalam cara yang animistik.]

Keywords: local Islam, animism, religious personhood, interpersonal relation.

\section{A. Introduction}

This paper examines Ammatoans' religious practices ${ }^{1}$ as professed to be "Islamic" by practitioners but contested as "animistic" by scholars. In academia and public discourse, Islam and animism are perceived to be distinctive and contradictive: they are mutually exclusive. A Muslim cannot be an animist, and vice versa. Once an animist converts to Islam, he or she must leave his/her animistic belief and practices. Otherwise, he or she would commit hypocrisy and heresy.

Since their first contact with Islam in the seventeenth century, Ammatoans have professed to be Muslim but continued practicing their (pre-Islamic) traditional practices, regardless of several spiteful and continual pressures by the state and outsiders. Those practices are the means and objectives for their collective identity reproduction. Their collective identity is built on the basis of interpersonal relationships among a wide range of beings including the land, trees, mountains and animals, as well as humans. For scholars working on Ammatoans like Penard, ${ }^{2}$ Renre, ${ }^{3}$ Usop, ${ }^{4}$ and Rossler, ${ }^{5}$ Ammatoans' religious practices are syncretic: Islam and Ammatoans' "animistic" tradition come together and

${ }^{1}$ Ammatoa is a minority Konjo-speaking community of approximately 4600 people living in the southeast uplands of South Sulawesi, Indonesia.

${ }^{2}$ W.A. Penard, “De Patuntung' of South Sulawesi, Malakaji”, Tijdschrift voor Indische Taal-, Land-en Volkenkunde, vol. 55 (1913), pp. 515-43.

${ }^{3}$ Abdullah Renre, Patuntung di Kecamatan Sinjai Barat (Ujung Pandang: Institut Agama Islam Negeri Alauddin, 1978).

${ }^{4}$ K.M. Usop, Pasang ri Kajang: Kajian Sistem Nilai di "Benteng Hitam" Amma Toa (Ujung Pandang: Pusat Latihan Penelitian Ilmu-Ilmu Sosial UNHAS, 1978).

${ }^{5}$ Martin Rössler, "Striving for Modesty: Fundamentals of the religion and social organization of the Makassarese Patuntung”, Bijdragen tot de Taal-, Land-en Volkenkunde, vol. 146, no. 2 (1990), p. 289-324. 
shape a new religious practice, ${ }^{6}$ but the traditional ones are gradually going to become extinct. ${ }^{7}$ For the state, the profession to be Muslim is a way to lead the ("uncivilized") Ammatoans to modernity. Ammatoans' traditional practices compatible with Islam and series of the state programs are for the state to be preserved for tourist interests. For orthodox Muslims, Ammatoans' religious practices are hypocritical and/or heretical because Islam and animism are mixed in practices. For them, the Ammatoans worship God but they also worship 'natural forces.'

In contrast, this paper shows that Islam and animism are not only complementary but also all-encompassing. Based on Ammatoans' religious phenomenon, this paper demonstrates that it is a misperception to essentially understand Islam and animism as mutually exclusive. To construct the argument, this paper refers to Nurit Bird-David's "Animism Revisited" in that she argues that animism should be understood as a relational epistemology. Bird-David demonstrates that the Western scholarship has misleadingly advocated that animism is a failed epistemology and Western scholars therefore have misunderstood that indigenous people's animistic epistemology fails to understand their world. Bird-David proves that Western scholars have ethnocentrically limited the notion of personhood to human beings only when discussing indigenous peoples' lives. In contrast to Western perception, Bird-David advocates, indigenous peoples like the Nayaka of India extend the notion of personhood to non-human beings. Through the indigenous notion of personhood, as this paper will show, Ammatoans observe their religious practices by locating Islam and animism (the indigenous religion) together.

Based on Bird-David's concept of animism that this paper interprets Ammatoans' religious practices, especially those related to their interactions with the forest, trees, land, and animals. Ammatoans' religiosity is predicated on the assumption that all of these beings are equal social actors. Unlike conventional interpretations on interactions

${ }^{6}$ This theory is, however, questionable for several reasons. 1) Ethnographically, the Ammatoa indigenous religion still persists in its own shape. So, it is rather dissimilation than syncretic. 2) In term of practice, Islam does not replace the indigenous ones and the absence of Islamic elements does not invalidate Ammatoan practices, and 3) syncretism often implies "impurity".

${ }^{7}$ Interestingly, researchers and scholars from 1913 up to present time all refer to the same practices where Islam and the indigenous religion are both present. This fact signifies that since the contact with Islam, the Ammatoan practices continue to play.

${ }^{8}$ Nurit Bird-David, “'Animism’ Revisited: Personhood, Environment, and Relational Epistemology”, Current Anthropology, vol. 40, no. S1 (Feb 1999), pp. 67-91. Al-jämi'ah, Vol. 52, No. 1, 2014 M/1435 H 
between Ammatoans with other beings, such as "worship" and, therefore, heretical or hypocritical (mushrik), this paper interprets that Ammatoans' (religious) ways of relating to their environment is "interpersonal." Drawing insights of Bird-David, ${ }^{9}$ Hallowell ${ }^{10}$ and Morrison, ${ }^{11}$ this paper argues that Ammatoans visit their forest because they perceive that the forest helps the well-being of Ammatoans. Their religious system based on personhood perception requires them to refrain from activities that may harm or offend other beings. They must avoid activities such as constructing paved roads or using electricity in their territory.

Islam, for Ammatoans, is a source of knowledge of how to perceive the world interpersonally. In what follows, this paper presents the notion of personhood from both indigenous and Quranic perspectives. This paper argues that both sources in discussing the notion of personhood correspond to one another respectively. At the end, this paper uses these two perspectives in interpreting Ammatoans' practices and argues that Ammatoans' practices are animistic Islam.

\section{B. Defining Personhood: Indigenous Perspectives.}

In contrast to Western sciences that perceive personhood as identical with human, ${ }^{12}$ indigenous perception extends personhood not only to human beings but also to non-human beings such as animals, trees, mountains, stones, thunder, and so forth. To construct an indigenous definition of 'personhood,' I build on the work of three scholars (Hallowell, Morrison, and Bird-David). Hallowell argues that the Ojibwa cosmos is occupied by persons: both human and non-human beings. Hallowell accounts the kinship term, grandfather, to establish the perspective in that he finds that the term grandfather is not only applied to human persons but also to a category of non-human persons. ${ }^{13}$ Hallowell explains that the non-human grandfathers are sources of power in that they share with human beings and therefore enhance the

${ }^{9}$ Ibid.

${ }^{10}$ A. Irving Hallowell, “Ojibwa Ontology, Behavior, and World View”, in Teaching from the American Earth: Indian Religion and Pbilosophy, ed. by T.B. Tedlock (New York: Liveright, 1960), pp. 17-49.

${ }^{11}$ Kenneth Morrison, "The Cosmos as Intersubjective: Native American OtherThan-Human Persons", in Indigenous Religions: A Companion, ed. by Graham Harvey (New York: Cassell, 2000), pp. 23-36.

${ }^{12}$ Michael Carrithers, Steven Collins, and Steven Lukes (eds.), The Category of the Person: Anthropology, Philosophy, History (New York: Cambridge University Press, 1985).

${ }^{13}$ Hallowell, "Ojibwa Ontology”, p. 144. 
power of human beings. ${ }^{14} \mathrm{He}$ conceptualizes personhood as the principal Ojibwa ontological category that is found in the Algonkian language, oral tradition, metamorphosis, and dreaming. In dreams, for example, Hallowell ascertains that the Ojibwa have direct encounters with other non-human persons. For non-human persons, Hallowell writes:

Like myself, they have personal identity, autonomy, and volition. I cannot always predict exactly how they will act, although most of the time their behavior meets my expectations. In relation to myself, other 'persons' vary in power. Many of them have more power than I have, but some have less. They may be friendly and help me when I need them but, at the same time, I have to be prepared for hostile acts, too. I must be cautious in my relations with other 'persons' because appearances may be deceptive. ${ }^{15}$

Hallowell contends that the category 'person' is central to understanding the Ojibwa cosmos. He argues that the Ojibwa concept of personhood includes both human and non-human beings such as stones, lightning, and thunder. To support his argument, Hallowell closely examines the grammatical structure of Ojibwa language that formally expresses a distinction between "animate" and "inanimate" nouns and concludes that the substantives for some --but not all-- trees, sun and moon, thunder, stones and other material culture such as certain kettles and certain pipes are classified as animate. ${ }^{16}$ Hallowell, however, argues that the Ojibwa are not animists in the sense that they dogmatically attribute living souls to inanimate objects, such as stones. ${ }^{17}$ Hallowell demonstrates that these beings constitute personhood through a crucial test in experience or encounter. ${ }^{18}$ Hallowell explicates that the recognition of animacy, thus personhood, is based on interaction between beings, be they humans or non-humans through dreams and visions. Hallowell discovers that the Ojibwa conceive thunder birds as acting like human beings: they hunt, talk and dance. ${ }^{19}$ He also learns that in their daily life the Ojibwa behavior towards certain plants and animals is culturally structured in that they deal with persons who understand what is being said to them and have volitional capacities as well. ${ }^{20}$ In short, Hallowell
${ }^{14}$ Ibid.
${ }^{15}$ Ibid., p. 168.
${ }^{16}$ Ibid., p. 146.
${ }^{17}$ Ibid., p. 147.
${ }^{18}$ Ibid., p. 148.
${ }^{19}$ Ibid., p. 157.
${ }^{20}$ Ibid., p. 160. 
convinces that the Ojibwa live in a world transcending social relations, a world of interpersonal relations among many different beings. ${ }^{21}$

Hallowell's theory is developed by Morrison. He develops the concept of person, power, and gift for theorizing interpersonal relations between human and non-human persons. For Morrison, the concepts of person, power, and gift are interrelated: person is constituted through intentionality (desire, need, will, purposefulness, selfishness, selflessness) by different beings; plants, animal and human beings, power --the ability to influence other beings-- is obtained through interpersonal relations and gift is the ethical responsibility or the means for creating and maintaining interpersonal relationship.

Morrison advocates that the Ojibwa do not define person by human physical shape and therefore they do not anthropomorphize. ${ }^{22}$ Morrison demonstrates that Ojibwa people perceive animals, plants, the Sun, Moon, and stars, and even 'objects' as persons because they behave like human beings do. ${ }^{23} \mathrm{He}$ detects that behaviors and actions of non-human persons are expressed in myth and lore and it is through myth and lore powerful persons are remembered.$^{24} \mathrm{He}$ endorses Hallowell that human and other beings encounter each other in dreams and visions. Morrison explains, a dream is a state of consciousness bridging cosmological dimensions. In dreams, human persons encounter non-human persons and acknowledge mutual responsibility and their encounters motivate their daily life behaviors. ${ }^{25}$ In the Ojibwa world, Morrison accounts, human and other beings express mutual responsibility in a sense that respectful relations among persons create harmony and antagonistic relations create disorder such as hunger, illness and social estrangement. ${ }^{26}$ Morrison observes the notion of mutual responsibility by interpreting acts of hunting as mutual communication between human and animal persons: humans need to persuade animals to give their bodies and to convince them that they will reincarnate. ${ }^{27}$ Echoing Hallowell, Morrison persuades that the Ojibwa cosmos, inhabited by persons of different species constitutes a relational, behavioral and social system. ${ }^{28}$

${ }^{21}$ Ibid., p. 167.

${ }^{22}$ Morrison, "The Cosmos", p. 76.

${ }^{23}$ Ibid., p. 77.

${ }^{24}$ Ibid.

${ }^{25}$ Ibid., p. 78

${ }^{26}$ Ibid., p. 77.

${ }^{27}$ Ibid., p. 78.

${ }^{28}$ Ibid., p. 77. 
Morrison goes on to show that interpersonal relationships among beings is the source of power $^{29}$ and, therefore, recognizing other persons and exercising the relationship with them is necessary. As a result of his comparison on Hallowell's and Blackburn's, ${ }^{30}$ Morrison discovers that both the Ojibwa and Chumash orient to other beings as kinfolk, and kin status which defines power, privilege, and responsibility among beings. ${ }^{31}$ In Ojibwa and Chumash's perception, non-human persons present themselves as kinfolk, empower human beings through dreams and visions, and engage themselves in human daily life activities. ${ }^{32}$ Morrison advocates that kinship encompassing humans and non-humans is paramount for Native Americans. ${ }^{33}$ He furthermore argues that it is because the Native American cosmos is inhabited by persons, they locate power in the interplay of all sorts of persons and hence the notion of causality and personal intentionality are synonymous: the land having emerged is the purposeful action of their culture's hero, Nanabozho, nights and days and the course of seasons are the intentional actions of Winter, Summer, sun, moon and stars. As a result, all beings: bird, animals, as well as humans reveal similar purposeful interaction. ${ }^{34}$ Through these perceptions, Morrison argues, the Ojibwa shape their practical life ways. ${ }^{35}$

In relation to the concept of gift, Morrison demonstrates that in Native American religious life, power is always conceived as a gift that forges solidarity ${ }^{36}$ Morrison states that in order to achieve human wellbeing, the Ojibwa and other Native Americans should engage in gifting acts that ensure the well-being of other beings. ${ }^{37}$ Morrison states that it is for the gifting that rituals are observed and, therefore, rituals revolve around relational concerns. Morrison then convincingly argues that "ritual contextualizes human and non-human interaction" (Morrison 2000; 85). Through the triangle concepts: person, power and gift, Morrison persuades that the religious life of Native Americans is concerned with moral behavior and cosmic meaning through mutual responsibility and

${ }^{29}$ Ibid., p. 80.

${ }^{30}$ Thomas C. Blackburn and Kat Anderson (eds.), Before the Wilderness: Environmental Management by Native Californians (Menlo Park, CA: Ballena Press, 1993).

${ }^{31}$ Morrison, "The Cosmos", p. 79.

${ }^{32}$ Ibid., p. 77.

${ }^{33}$ Ibid., p. 84.

${ }^{34}$ Ibid., p. 82.

${ }^{35}$ Ibid.

${ }^{36}$ Ibid., p. 85.

${ }^{37}$ Ibid. 
interpersonal relationship among beings.

Having learned the ways of living of Nayaka, India, especially related to the idea of devaru, Bird-David develops the concept of sharing and relating among the Nayaka. In so doing, Bird-David focuses on Nayaka perception of personhood. Bird-David demonstrates that devaru is a 'superperson'38 manifesting in different beings such as stones, rocks, animals, plants, etc. Bird-David accounts Nayaka perception that some elephants and rocks are devaru and some are just elephants and rocks. Bird-David persuades that a being constitutes devaru when she shares and relates and it is through sharing and relating that personhood is mutually recognized by both fellow Nayaka and members of other species living in their environment. Bird-David advocates that preserving relationships and sharing activities among beings are critical to Nayaka identity because it is through those ways they maintain their personhood. Bird-David states that the Nayaka people establish their personhood by producing and reproducing their sharing relationship with surrounding beings, human and non-human others. Bird-David provides ethnographic data that show the Nayaka perceive the people (avaru) and other species --animals, plants, or other beings (devaru) as relatives or kinfolk (nama sonta = our family): they are in some contexts absorbed into one "we-ness". The notion of we-ness is exercised in devaru performances in which Nayaka people invite, relate and share with devaru (other beings presenting intention, desire, and will for sharing and relationship). Devaru performances are, in other words, the means to make known avaru-devaru relatedness.

Furthermore, Bird-David demonstrates that the Nayaka live in a social environment by conceiving themselves as 'dividual' rather than individual. She develops the concept of dividual to justify the uniqueness of the Nayaka way of life distinctive from Euro-American individual. Bird-David explains that dividual is "a person constitutive of relationship". 39 To make sense of the concept of dividual, Bird-David explores the verb "dividuate":

When I individuate a human being I am conscious of her "in herself" (as a single separate entity); when I dividuate her I am conscious of how she relates with me. ... I am conscious of the relatedness with my interlocutor

${ }^{38}$ She contrasts this term with Hallowell's other-than-human person. She chooses 'superperson' because she argues that other-than-human person falls under class category and therefore still conserves objective notions; Bird-David, “'Animism” Revisited", p. 74.

${ }^{39}$ Ibid., p. 72. 
as I engage with her, attentive to what she does in relation to what I do, to how she talks and listens to me as I talk and listen to her, to what happens simultaneously and mutually to me, to her, to $u s^{40}$

By dividual perception, argues Bird-David, the Nayaka sense a person as whom they relate and share with. That sense of personhood, thus, applies not only to humans but also to non-humans. For Bird-David, dividual is emergent, constituted by relationships, not given and must be worked out through social processes. ${ }^{41}$

To conclude, the three scholars agree that animists do not limit the notion of personhood to humans only but also extend it to non-human beings. This notion of personhood is also shared by Ammatoans. They practice Islam through the exercise of their animistic notion as this paper argues. In the following, I examine the Quranic accounts that relate to non-human beings in order to justify the argument that the animistic perception of personhood corresponds to the Quranic accounts. This paper finally presents Ammatoans' religious practices as exemplifying being Muslim in animistic ways.

\section{The Personhood of 'non-Humans' in the Quran}

Though it is controversial, I advocate that the animistic perspective of personhood is prevalent in the Quran. Both scholars and Muslims assume that human beings are better than or superior to any other beings. This assumption limits personhood to human only. Foltz for example shows that the Quran itself depicts humans as occupying a special and privileged status. Foltz refers to the Quranic verses that declare that human is the best creature (95: 4), animals is for human benefits (22: $65 ; 16: 5-8,12,14 ; 6: 142)$, eating animal flesh is allowed $(5: 1 ; 6: 145 ; 16$ : $5,66 ; 40: 79)$, and slaughtering animals is lawful $(5: 3 ; 2: 173 ; 6: 145)$. In addition to those verses, Foltz documents that the Quran repeatedly mentions the words of faddalna (we made them to excel the others), karramna (we made them more gracious), ja'ala lakum (we created them for you), b̧amalna (we bring them for you), and the like that are all for human superiority. Referring to different sources of Islam: the Quran, the Hadith, the Islamic law, Islamic philosophy and science, Foltz argues that in all these expressions of Muslim culture, animals are valued mainly for the service they provide for humans, though sometimes animals could

\footnotetext{
${ }^{40}$ Ibid.

${ }^{41}$ Ibid., p. 73. 
provide lessons which human can draw from them. ${ }^{42}$

\section{Conceptualizing Khalifa (Stewardship): the Superiority of Human Beings}

To begin the discussion, I examine first the established Quranic interpretation of stewardship in which most Muslims contend the superiority of humans over other beings. In the Quran, the word khalifa, together with its derivation (khulafä' and khalaifa), is mentioned nine times: $2: 30 ; 6: 165 ; 7: 69,74 ; 10: 14,73 ; 27: 62 ; 35: 39 ; 38: 26$. Two verses refer to an individual: 2: 30 (Adam) and 38: 26 (Daud/David), three verses refer to a certain group: 7: 69 (a people coming after the people of Noah), 7:74 (a group of people coming after the people of 'Ad), and 10: 73 (the people of Noah), and four verses refer to all humankind: 6 : 165; 10: 14; 27: 62; and 35: 39. In the English translations of the Quran, the word khalifa has been translated with several meanings. Yusuf Ali uses vicegerent, agent, inheritor and heir in his translation. Muhammad Asad uses inheritor, heir, successor and vicegerent. Picktall only uses viceroy to translate the nine verses of khalifa. Shakir translates khalifa with successor and ruler and al-Hilali and Khan translate the word as generation, successor and inheritor.

Al-Zamakhshāry, in his al-Kashshäf, al-Shaukāny in his Tafsìr Fatḥ alQadìr, Ibn Kathīr in his Tafsì al-Qur'àn al-'Az̧ìm, all agree in interpreting the word khalifa as "successor" or "the one who substitutes the others" or "a group substitutes other groups". In interpreting the word khalifa as used in 2:30 for instance, they agree that Adam as the khalifa of God replaces angels on the earth. Unlike the two other interpreters, al-Zamakhshary implies that the status of khalifa as successor is given to Adam in his capacity as the prophet and therefore all other prophets carry the status of khalifa. In other words, al-Zamakhshary would argue that the status of khalifa is not given to all human beings but rather to only certain people whom God has chosen to carry about.

In conceptualizing khalifa, the Quranic commentators do not only take the nine verses of khalifa but also relate to some other Quranic verses and the prophet's Hadiths. In doing so, their references to other verses and Hadiths determine their assessment of what khalifa means. In this paper, I choose only those who have concerns with environmental issues in constructing the theory of khalifa. My goal is to point out that despite a strong assumption privileging humans over other beings, there

${ }^{42}$ Richard Foltz, Animals in Islamic Tradition and Muslim Cultures (Oxford: Oneworld, 2006), p. 4. 
have been concerns among Muslim scholars with the issue being under discussion. Some of them, as we shall see, however, do not fully account the personhood of non-humans.

Al-Damkhi defines khalifa as "one who takes over a position, a power, a trust, and who holds it reliably and in harmony with its grantor (Allah/God)". "Al-Damkhi defines the verbal root of khalifa, khaläf, as 'he came after, followed, succeeded.' Al-Damkhi argues that Adam, the prophet and the progenitor of the human race was appointed by God as khalifa on earth. Consequently, argues al-Damkhi, every man or woman has inherited power and accountability in relation to the earth's resources and all its life forms ${ }^{44}$ Supporting his argument, al-Damkhi refers to the 17: 70. In interpreting 2:30, al-Damkhi, however, argues that the khalifa was seen to break the rule and violate the trust, and showed himself unworthy to be preferred over other beings. For al-Damkhi, only because do human beings violate the rule and trust of being khalifa, human beings are not superior. Al-Damkhi furthermore relates the notion of khalifa to the concept of amanna (trust) by referring to 33: 72. The Quran 33: 72, according to al-Damkhi, implies that God offered the trust to human beings and they accepted the responsibility with their abilities of choosing their relative free will, and thus human beings gain the capacity to live for good and evil. Being a khalifa on earth, al-Damkhi explains, man must fulfill the amanna (trust) through acting truthfully in agreement with God's laws. ${ }^{45} \mathrm{Al}$-Damkhi contests human superiority over others, but only in conditional ways. If conditions like amāna are fulfilled, humans deserve superiority.

Similarly, by referring to verses in which God subjugates (sakbkhara) the sun and moon, day and night, the rivers and the sea, and indeed everything for humans $(14: 33,16: 12,29: 61,31: 29,35: 13,39: 5 ; 14: 33$, $16: 12 ; 14: 32 ; 16: 14 ; 31: 20,45: 13)$, Yasin Dutton argues that all humankind as the children of Adam share the attribute of khalifa-dom as being God's deputy or representative on Earth. For Dutton, God has created everything for humans as gifts and therefore humans are free to use the good things of the earth. To treat those gifts, Dutton, however, argues that humans are bounded with their 'abd-ness (servanthood), which is to

${ }^{43}$ Ali Mohamed Al-Damkhi, "Environmental ethics in Islam: principles, violations, and future perspectives", International Journal of Environmental Studies, vol. 65, no. 1 (Feb 2008), p. 16.

${ }^{44}$ Ibid.

${ }^{45}$ Ibid., p. 17. 
follow the laws of God. ${ }^{46}$ In Dutton's accounts to say in short, human superiority is conditional. Just like al-Damkhi, when humans fulfill the conditions of 'abd-ness, they become superior. Personhood does not belong to other beings because they are all under control of human beings. For Dutton, the condition of other beings is dependent on human beings' control.

Focusing specifically on the Quran, 6: 165, Saadia Khawar Khan Chisti, along with Dutton, argues that the Quran establishes a position for humans in the physical world as one of vicegerent, or steward, of creation. In the sharia, the earth, Chisti advocates, is presented to the vicegerent as a "usufruct" with attendant duties of maintenance and if possible, improvement for the benefit of the coming descendent generations. Chisti states that humankind is responsible for the survival and good condition of the various communities on the earth. ${ }^{47} \mathrm{Up}$ to this point, al-Damkhi, Dutton, and Chisti still account human beings as superior over other beings. They all advocate human superiority, despite their contestation on it, and so fail to recognize the personhood of other beings.

Citing the Quran, 6:38 and 16: 68, Chisti, unlike al-Damkhi and Dutton, argues that the Quran highlights the need for human sensitivity to its co-inhabitants (non-human beings) of the earth because Allah also communicates with them. ${ }^{48}$ It seems that Chisti realizes the notion of interdependence among living communities: humans and non-humans. In this context, Chisti goes on, every life-form possesses intrinsic value dependent of its resource worth to humanity. ${ }^{49}$ Chisti argues that as vicegerents, humans are obligated to balance their needs with the needs of the other communities and species that come under their care and responsibility. To do so, everyone is bounded by individual knowledge and by individual capacity. ${ }^{50}$ Even though Chisti privileges the superiority

${ }^{46}$ Yasin Dutton, "The Environmental Crisis of Our Time: A Muslim Response", in Islam and Ecology: A Bestowed Trust, ed. by Richard C. Foltz, Denny Frederick Mathewson, and Azizan Haji Baharuddin (Cambridge: Harvard Divinity School, 2003), pp. 8-9.

${ }^{47}$ Saadia Khawar Khan Chishti, "Fitra: An Islamic Model for Human and the Environment", in Islam and Ecology: A Bestowed Trust, ed. by Richard C. Foltz, Denny Frederick Mathewson, and Azizan Haji Baharuddin (Cambridge: Harvard Divinity School, 2003), pp. 75-6.
${ }^{48}$ Ibid., p. 76.
${ }^{49}$ Ibid.
${ }^{50}$ Ibid., p. 75-6. 
of human beings over other beings in theorizing khalifa, he seems to implicitly recognize the personhood of non-human beings because for him non-human species have their own needs, desires, and will.

Echoing Chisti and referring to Quran, 95, Othman Abd-arRahman Llewellyn argues that it is an honor for humans to be khalifa because they are created 'in the best of forms,' that is, with the greatest potential for good. Llewellyn's interpretation is here significant because many Muslims would interpret ahsan taqwim as 'the best creation.' For Llewellyn, if we are not aware of the potential or do not carry it accordingly, our status is even 'lower than the low.' Llewellyn states that khalifa is not a privilege, but a trust, a responsibility, and a trial that other beings such as heavens, the earth, and the mountains refused to bear: In managing (or interacting with) the earth, humans have proven themselves thoroughly unjust and foolish (33: 72) or broken the trust. In the Day of Judgment, Llewellyn argues, this khalifa will be a source of both pride to those who fulfill it and shame to these who break it. To be a khalifa, for Llewellyn, is to serve and not to receive. ${ }^{51}$ Llewellyn insists that humans will not fulfill the trust of being khalifa unless the horizons of care extend through space and time to embrace all other species, individuals, and generations of beings. Only through extending the care would humans be khalifa on the earth. ${ }^{52}$ Unlike the previous scholars, Llewellyn explicitly provides insight that being khalifa is to perceive interpersonal relationship among beings.

To follow Llewellyn's argument, I argue that the extension of the care requires recognition of others' needs and dues. This argument comes along with Sayyed Hossein Nasr's argument of khalifa in which Nasr relates the concept with haqq and 'abd. Nasr advocates that each being exists by virtue of the truth ( $($ aqq) and has its due (baqq) according to its nature: animals, trees and mountains have their own dues. Nasr argues that in interacting with nature, human beings must respect and pay what is due to each being, and all beings have their rights accordingly. For Nasr, Islam stands totally against the perception that human beings have all the rights and other beings have only what human beings decide to give them. For Nasr, it is God who has given the rights to beings (human

${ }^{51}$ Othman Abd-ar-Rahman Llewellyn, "An Islamic Model for Human and the Environment", in Islam and Ecology: A Bestowed Trust, ed. by Richard C. Foltz, Denny Frederick Mathewson, and Azizan Haji Baharuddin (Cambridge: Harvard Divinity School, 2003), p. 190.

${ }^{52}$ Ibid., p. 191. 
and non-humans) and therefore human beings have no right to take away the haqq of various beings..$^{53}$ Before God, human and non-humans have their own rights as well as responsibilities. Nasr contends that the Quran speaks of human beings as both servant of God ('abd Allab) and vicegerents of God (khalifat Allah) and both concepts have to be carried together at any time and place. Nasr argues that humans have the right to practice their vicegerency on the earth only on their status as God's servants ('abd) obeying His will and His Laws. Humans' rights (buquiq) over nature must follow their responsibilities toward God and the nature. ${ }^{54}$

Similarly, Haq argues that humanity commits to follow God's sharia, his way, which is not given to humanity as a fully articulated body of laws, but rather spread all over God's signs (āya) in the form of indicators with probative value (adilla). For Haq, the term aya appoints not only the Quranic verses but also the phenomena and the objects of the natural world. The natural world, Haq concludes, is a bona fide source for the understanding (figh) of sharia, and therefore cannot be considered subservient to human beings. ${ }^{55}$ Although both Nasr and Haq do not elaborate God's Will or Law, we could discern an insight that parts of what they mean by God's Law or Will is to recognize and respect other beings' dues (buquiq): desires, needs, intentions, and anything that constitutes personhood.

Nasr goes on to argue that nature is not there only for human use. The existence of the nature is to reflect the creative Power of God. Human beings are created to be a channel of grace for the cosmic atmosphere around them, and so do other beings for human beings. For Nasr, creatures in the world of nature not only have a relation with human beings and through them with God, but they also have a direct relation with God and possess an eschatological significance. Nasr contends that the Islamic paradise is full of animals and plants and is not only crystalline. According to Nasr, creatures will speak directly to God in the Day of Judgment ${ }^{56}$ as they also receive revelation (waby). Furthermore, Nasr

${ }^{53}$ Sayyed Hossein Nasr, "Islam, the Contemporary Islamic World, and the Environmental Crisis", in Islam and Ecology: A Bestowed Trust, ed. by Richard C. Foltz, Denny Frederick Mathewson, and Azizan Haji Baharuddin (Cambridge: Harvard Divinity School, 2003), p. 97.

${ }^{54}$ Ibid.

${ }^{55}$ S. Nomanul Haq, "Islam and Ecology: Toward Retrieval and Construction", in Islam and Ecology: A Bestowed Trust, ed. by Richard C. Foltz, Denny Frederick Mathewson, and Azizan Haji Baharuddin (Cambridge: Harvard Divinity School, 2003), p. 130.

${ }^{56}$ Nasr, "Islam, the Contemporary", p. 96. 
argues that the nature: be they animals, trees, plants, and mountains, is the abode of "spiritual" presence and source for the understanding and contemplation of divine wisdom. Humans' need for nature therefore is not merely to feed and shelter their physical bodies, but also and above all to nurture their well-being. For Nasr, as the complement to the Quran as revelation, the nature is there for humans' well-being. ${ }^{57}$ For him, interdependency of both humans and non-humans is sunnatullahb (God's Law) and to exercise it is necessary for the well-being of both parties. Compared with other scholars, Nasr provides the strongest insight that both human and non-human beings could be 'person.'

\section{Non-Human Beings are Muslims}

Another issue to examine the Quranic perspective on personhood is muslim-ness of non-humans. I contend that the nature or all beings are muslim. Referring to the Quran 51:56, Muslims believe that the creation of human beings is to serve God. Saba Mahmoud ${ }^{58}$ learns from Muslim women in Egypt that their ritual salat (the five times daily prayers) is both means and ends which means that prayers is the means to reach the goal of being Muslim and also is itself the destination of being Muslim because salat is what they believe to be the reason God creates humans. Based on this Muslim women's perception as explained by Mahmoud, I argue that the personhood of a Muslim is seen and valued through his/ her acts of serving God.

The other way is to examine what means to be muslim because being muslim (taking the word "muslim" as a person who commits to islam) itself constitutes personhood. I take the word muslim and islam differently from Muslim and Islam (with capital M and I respectively). The former constitutes the inclusive meaning, which refers to any person who commits serious relationship with God and the letter refers to the exclusive meaning, which refers to the followers of Islam founded by the prophet Muhammad.

Ibrahim Ozdemir explains that muslim comes from the word islam, and the word islam derives from $s-l-m$, which means "to be safe," "to be whole and integral","not to be disintegrated". ${ }^{59}$ Fazlur Rahman explains

${ }^{57}$ Ibid.

${ }^{58}$ Saba Mahmood, Politics of Piety: The Islamic Revival and the Feminist Subject (Princeton: Princeton University Press, 2005).

${ }^{59}$ Ibrahim Ozdemir, "Toward an Understanding of Environmental Ethics from a Qur'anic Perspective", in Islam and Ecology: A Bestowed Trust, ed. by Denny Frederick Al-Jämi'ah, Vol. 52, No. 1, 2014 M/1435 H 
that the fundamental idea of being muslim is to "accept," "submit," and "surrender" to the Law of God. ${ }^{60}$ Taking this definition, I then hold that muslim includes not only humans but also non-humans, for all beings: humans and non-humans accept the Law and Will of God. Abdul Aziz Said and Nathan C. Funk argue that all beings: human and non-human beings share in the existential condition of submission to the Divine. They contend that all creatures are necessarily muslim because, consciously or unconsciously, they observe the will of Allah ${ }^{61}$ that encompasses natural law.

Needless to say that those above arguments are Quranic based. To follow them, I construct the argument that what constitutes to be muslim is to accept the Law of God, which could mean both sharia and what socalled sunnat Allab and to worship God. As repeatedly mentioned in the Quran that the heaven and the earth, and all beings living in or in between glorify $(57: 1 ; 59: 1 ; 61: 1 ; 17: 44 ; 24: 41 ; 59: 24 ; 62: 1 ; 64: 1)$ and prostrate to God $(13: 15 ; 16: 48,49 ; 22: 18),{ }^{62}$ it is necessary to argue that according to the Quran the whole cosmos is muslim. The Quran even gives some details about other beings that glorify God such as mountains and birds (21:79; 38:18), thunder (13:13), stars and trees (55:6). To this point, I argue that muslim-ness, which is to accept, submit, and surrender to God's sharia or Law, constitutes personhood of all creatures. Both humans and non-humans share muslim-ness (and thus personhood) through the acceptance and submission to the law of God (sharia).

That some people are not muslim is because they disbelieve or refuse to follow God's Law or sharia and therefore they destroy their personhood. Some might argue that because of humans' relative free choice of believing or disbelieving God, or following or transgressing God's sharia, humans are the agents of themselves. Although agency Mathewson and Azizan Haji Baharuddin (Cambridge: Harvard Divinity School, 2003), p. 34 .

${ }^{60}$ Fazlur Rahman, "Some Key Ethical Concepts of the Qur'an", The Journal of Religious Ethics, vol. 11, no. 2 (1983), p. 183.

${ }^{61}$ Abdul Aziz Said and Nathan C. Funk, "Peace in Islam: An Ecology of the Spirit", in Islam and Ecology: A Bestowed Trust, ed. by Richard C. Foltz, Frederick Mathewson Denny, and Azizan Haji Baharuddin (Cambridge: Harvard Divinity School, 2003), p. 157.

${ }_{62}$ Abdullah Yusuf Ali notes that the word ma connotes inanimate beings and man refers to animate or living beings. Since both words are used in the Qur'an, both inanimate and living beings are worshipping God; Abdullah Yusuf Ali, The Meaning of the Holy Qur'an: New Edition with Revised Translation, Commentary, and Newly Compiled Index, 10th ed. (Beltsville: Amana Publications, 2003). 
is beyond the issue in this paper, it could be argued that if agency is conceived as being able to choose (to accept or to refuse), non-human beings: the heaven, the earth and mountains are also agents because the Quran also speaks so. The Quran, 33: 72, for example, states that the heaven, the earth, and the mountains refused to accept amana (a trust or a certain responsibility), which was then offered to human beings. Also, the Quran, 59: 21, declares that a mountain would be humble had the Quran been offered to it. Humbleness is a state of which a muslim should pursue and exercise.

This notion of muslim-ness is the paradigm I bear to read the Quranic verses that are questionably interpreted to give superiority to human over other beings. Yusuf $\mathrm{Ali}^{63}$ translates the word $s-k h-r$, which is mentioned twenty one times in the Quran ${ }^{64}$ as "subject" (God makes them subject or God subjects them to you --human beings for use). Yusuf Ali understands those verses as the benefits for humans to fulfill their needs by using all other beings. Unlike Yusuf Ali, I argue, to the contrary, that the word s.kh.r. connotes that God has made the ways of non-humans: the sun, moon, stars, mountains, sea, land, the heaven, the wind, and so forth, showing their intentionality and purposeful actions understandable to humans for mutual interaction. That everything follows a course as mentioned in the Quran (31:29; 35:13; 39:5; 38:36) is for all beings: human and non-humans to recognize the intentionality, responsibility, needs, desires, dues, and personhood of each other. Now, through the examination of the Quranic concept of stewardship and muslim-ness, I prove that this Quranic perspective corresponds to the indigenous perspective of personhood.

\section{Animistic Practices of Islam: the Ammatoans of Sulawesi, Indonesia}

I state in the beginning that Islam and animism are all encompassing. After constructing the Quranic perspective of personhood that corresponds to indigenous perspective, here I re-interpret some religious activities of Ammatoans that have been ethnocentrically claimed to be "animistic" (belief in spirit) by both scholars and Muslim outsiders. For

${ }^{63}$ Ibid.

${ }^{64}$ The Sun and moon: 13:2; 14:33; 29: 61; 31:29; 35:13; 39:5, Ship: 14: 32, days and nights: $14: 32: 14: 33$, nights and days, sun and moon: 16:12, the sea: 16:14; $45: 12$, all creatures in the earth and in the heaven: $22: 65 ; 31: 20 ; 45: 13$, livestock: $43: 13$, mountains and birds: 21:79; 38:18, the wind: 38: 36; 69:7, and camels: 22:36, 37. 
practitioner themselves, however, those religious activities are what they have to religiously perform as Muslim (and of course as Ammatoan). Those activities and performances of Ammatoans under questions are both the collective and individual activities. For collective events, activities and performances consist of series of rituals: 1) panganroang ("invocation") which is conducted when Ammatoans have a long dry season, the harvest is not successful, or someone transgresses their adat (tradition). Ammatoans perform panganroang in a certain site called Tombolo in their forest and visit the site every year; 2) thanksgiving, which is conducted in another site called Possi'tana Sapo (the center of the earth) in their forest. They perform this ritual after their harvest. They also visit Possiktana Sapo three times in a year to solve their problems; 3) rites of passages that consists of dallek mbuak (sunrise) or ritual of birth, akeattere (cutting hair) for a baby when she or he is around 1 year old, circumcision, wedding ritual, and dallek sakra (sunset) or funeral. The funeral itself consists of three stages: baca doang (chanting) attended by family only, lajo-lajo (mourning) attended by some community members, and dampo (to deliver) attended by many community members, including a Muslim imam with animal sacrifices. In all these rituals or events, the recitation of oral tradition (Pasang ri Kajang) becomes the most fundamental element. For individual daily life activities, they consist of individuals working in the field, fishing in the ocean, working in domestic activities such as cooking and cloth-making, which always involve the chanting of their oral tradition, and wearing uniform black clothes on daily basis.

Unlike other scholars who have described those practices as "animistic" in the sense of belief in spirits inhabiting the natural objects and as worshipping the natural objects, ${ }^{65} \mathrm{I}$ argue, to the contrary, that those performances are "animistic" in the sense of constituting interpersonal relationship and parallel to the Quranic accounts as elaborated above. Panganroang (invocation) ritual, which is conducted at least for three conditions, should be interpreted as Ammatoans' ways of relating and interacting with (and not worshipping) non-human beings. Long dry season and unsuccessful harvest are intentional actions of other beings (persons) to which Ammatoans need to respond by visiting their forest where they negotiate the rights and responsibilities of both parties: humans and non-humans. If someone transgresses their adat (tradition or ethical law) that include cutting a tree(s) without replacing them, they

${ }^{65}$ Usop, Pasang ri Kajang; Rössler, "Striving for Modesty". 
also visit their forest. ${ }^{66}$ The forest they annually visit is another person in the Ammatoans' perception. They perceive that forest is a source of life. ${ }^{67}$ From that forest, no one is allowed to take anything out: like fruits, trees, woods, or animals unless they notice that those coming from the forest offer themselves to Ammatoans. ${ }^{68}$ For instance, if Ammatoans see an animal in the forest, they initiate an encounter by approaching the animal. Have the animal stayed in place, Ammatoans would take and could slaughter the animal because they perceive that the animal should have offered himself as a gift to Ammatoans. If the animal, however, runs, Ammatoans would not do anything but let the animal run away. Ammatoans do not hunt animals. ${ }^{69}$

After having successful harvest, Ammatoans perform thanksgiving ritual by visiting another site called Possiktana Sapo (the center of the earth) in their forest to which they visit three times in a year. ${ }^{70}$ Harvest, either successful or unsuccessful, is purposeful actions of plants that Ammatoans respond to. In this ritual, Ammatoans bring parts representing of whatever they have harvested such as rice, corn, or banana (cooked and uncooked) with them to Possi'tana. In Possi'tana, they eat the cooked ones and leave the uncooked ones. An Ammatoan said, "we leave them for the forest, so that we could get some back from the forest." In contrast to Syamsuddin ${ }^{71}$ who interprets this statement that Ammatoans make offerings to "spirits" (I am still struggling to search for parallel word of spirit in Indonesian and in the local Sulawesinese languages: Makassarese, Buginese, and Konjo of Ammatoans) of the forest, I argue instead that Ammatoans perceive the forest as a person that they need to share with for the well-being of both parties. For the sake of a cosmic balance, whatever Ammatoans harvest is not merely for their benefit, but always to share with others: both humans and non-humans. ${ }^{72}$

${ }^{66}$ Munirah Sirajuddin, Mencermati Makna Pesan di Kajang (Surabaya: Citra Adi Bangsa, 2002).

${ }^{67}$ Ibid., pp. 52-5.

${ }^{68}$ Abdul Muttalib, "Arti Positif Sikap Isolasi Masyarakat Kajang”, presented at the Temu Budaya Sulawesi Selatan (Ujungpandang: Kanwil Depdikbud Sulawesi Selatan, 1998).

${ }^{69}$ Syamsurijal Adhan, "Islam dan Patuntung di Tanah Toa Kajang: Pergulatan Tiada Akhir", in Hak Minoritas: Dilema Multikulturalisme di Indonesia, ed. by Hikmat Budiman (Jakarta: Interseksi Foundation, 2005).

${ }^{70}$ Sirajuddin, Mencermati Makna.

${ }^{71}$ Ibid.

${ }^{72}$ Catherine McKanzie, "Origins of Resistance: The Construction and Continuity of Identity in Tana Towa (Bulukumba, South Sulawesi, Indonesia)", Ph.D. Al-Jämi‘ah, Vol. 52, No. 1, 2014 M/1435 H 
There are several points worthy to add up to the Ammatoan notion of personhood from the rites of passages. Both ritual of birth and funeral are related to the sun: the ritual of birth is called sunrise (dallembuak) and funeral is called sunset (dallek sakra). Sunrise and sunset might be seen as merely names of ritual. But if we relate to their perception that the sun is the teacher enlightening human beings, the names are not insignificant. The names should have more meaning. It is a person "who" enlightens Ammatoans. Because of their perception about the sun, assumingly their houses uniformly facing the east are for Ammatoans to welcome (respond the encounter with) the sun every morning. Another interesting fact in rites of passage is in their wedding. Every new couple should start a family life with at least a couple of livestock. Economically, livestock would assure the good life for a new couple who just start their new life or are responsible for their own life. According to their myth, the Ammatoaans have been living with livestock from the beginning and therefore livestock have become their fellows. The Ammatoan kinship system also embraces non-human beings. Dragons and eagles are among Ammatoans' ancestors. ${ }^{73}$

Working in the field, fishing in the ocean, and working in domestic activities such as cooking and cloth-making, individuals always chant their Pasang ri Kajang (oral tradition). Pasang ri Kajang literally means the massages of Kajang, the name of an area where Ammatoans reside. The Pasang is the wisdom of elders. ${ }^{74}$ The Pasang is typically short, poetic saying and sets out key expressions of community ethos, strict prohibitions in daily life conduct, truth distilled from collective knowledge and experiences, specific advices or admonitions for community members. The Pasang encodes the entire religious, ceremonial and social system of Ammatoans and is handed down from generation to generation. ${ }^{75}$ The Pasang counsels a simple life as a virtuous life and thus simplicity is one of the core teachings of the Pasang. ${ }^{76}$ It forbids the introduction of any non-traditional elements, such as electricity and schools, into Ammatoans' life and it is then as the means of channeling community practices and as self-representation. ${ }^{77}$ Through their chants of the Pasang in working, Dissertation (Sydney: Australian National University, 1994), p. 107.

${ }^{73}$ Usop, Pasang ri Kajang.

${ }^{74}$ Ibid.; Rössler, "Striving for Modesty".

${ }^{75}$ McKanzie, "Origins of Resistance", p. 74; Usop, Pasang ri Kajang, p. 119.

${ }^{76}$ Samsul Maarif, "Dimensions of Religions Practice: The Ammatoans of Sulawesi, Indonesia", Ph.D. Dissertation (Arizona: Arizona State University, 2012).

${ }^{77}$ McKanzie, "Origins of Resistance", p. 54. 
Ammatoans manifest their knowledge, cultivate their daily behaviors, and surely communicate with those they interact with: the field rice, farms, and the ocean. In these individual activities, we again see how Ammatoans embrace the notion of 'indigenous' personhood.

The last thing to examine in regard to the Ammatoan concept of personhood is their unwillingness to accept modern agendas such as schooling, building hospitals, paving the roads, farming by modern technological tools, and so forth. ${ }^{78}$ On daily basis, Ammatoans wear uniform black clothes, no sandals or shoes, or no electricity. The state champion of 'progressiveness' through formal educatioan and development of modern technology is contested by Ammatoans. For Ammatoans, the best knowledge is to patuntung (seek and practice) Pasang ri Kajang. ${ }^{79}$ Seeking for knowledge is not through 'formal' schools (as imposed by the state) but being sabbara' (patient), lambusu' (honest), and gattang (consistent and persistent). ${ }^{80}$ Unlike the state that would assume health as being physically healthy, Ammatoans perceive health as manifesting adat (tradition) based on Pasang ri Kajang that counsels simplicity and ethically, politically, economically and socially governs the community members, including in relation to their environment. Paving the road is conceived unethical by Ammatoans. Ammatoans perceive that paving the road would offend non-human others who live in their environment. ${ }^{81}$

\section{E. Concluding Remarks}

Ammatoans' practices are both to implement their cosmological perception that counsels interpersonal relationship and to cultivate their desire to be Ammatoan: honest, consistent and persistent, and patient. Practices are both the ways to discipline their 'self' especially in relation to other beings and products of their perception about the world. Ammatoans do not distinguish between knowledge and practice. For Ammatoans, sabbara' (patient), lambusu' (honesty), gattang (consistency), are knowledge that they pursue through practices in daily basis. This notion is again similar to the Quranic account from the 61:3: "Grievously odious

\footnotetext{
${ }^{78}$ Maarif, "Dimensions of Religions".

${ }^{79}$ Renre, Patuntung.

${ }^{80}$ Sitti Aminah, Nilai-nilai Lubur Budaya Spiritual Masyarakat Amma Toa Kajang (Ujung Pandang: Depdikbud Provinsi Sulawesi Selatan, 1989).

${ }^{81}$ Rössler, "Striving for Modesty", pp. 313-4. 
is it in the Sight of God that ye say that which ye do not". ${ }^{82}$

For such practices, Foucault ${ }^{83}$ would argue that Ammatoans continually observe the "care of the self," "discipline the self," and "transform the self" in order for the self to better understand and interact with others and the world. Going beyond Foucault's limited account on personhood (or in his term 'selfhood') that applies to human only, Ammatoans take care, discipline and transform the self in order to engage interpersonal relationship that produce the well-being of persons: human and non-humans. For Ammatoans, the care of the self is not confined with humans only but extended to other beings. Ammatoans discipline and transform the self through interaction and encounter with other beings: humans and non-humans. Through interaction and encounter (by visits, chants, or rituals), Ammatoans cultivate their mutual recognition and understanding with other persons and therefore mutual rights and responsibilities could be exercised. Furthermore, exercising interpersonal relationship is for Ammatoans to establish social unity of beings. Adhan accounts the notion of social unity of beings by referring to the Pasang that says: 'abbulo si pappa, allemo sibatu, tallang si pabua, manyu siparampe, and lingu sipakainga' (in disperse we unite, in weakness we strengthen, in dip we hold up, in drift we help, and in forgetfulness we remind). Based on his ethnographic data, Adhan persuades that the Pasang is not only to address the social unity of human beings but also that of other beings living in the environment. ${ }^{84}$

It is a challenge to argue about Ammatoans' practices whether they are Quranic based or not. Historically speaking, Ammatoans have professed to be Muslim since $17^{\text {th }}$ century. They, however, used to refuse bringing the Quran inside their territory. Their refusal is consulted in their Pasang. ${ }^{85}$ Imposed by the state, some of their children have come to schools where they are taught about the Quran. Two possibilities about the study of the Quran could tell. First, the study is basic: how to read the Quran or basic teaching of Islam such as the Five Pillars because the schools are from $1^{\text {st }}$ to $9^{\text {th }}$ grades and they are the state (secular) schools. In this case, it is doubtful to argue that Ammatoans might acquire the

${ }^{82}$ Ali, The Meaning, p. 1460.

${ }^{83}$ Michel Foucault, The Hermeneutics of the Subject: Lectures at the College de France 1981-1982, ed. by François Ewald and Alessandro Fontana, trans. by Graham Burchell (New York: Picador, 2005).

${ }^{84}$ Adhan, "Islam dan Patuntung", p. 263.

${ }^{85}$ A.A. Cense, "De Patoentoengs in Het Bergland Van Kadjang", manuscript, Koninklijk Instituut voor Tall-, Land- en Volkenkunde collection (1931). 
Quranic perspective of personhood as described above just based on the formal educational processes. Second, the Quranic study being taught in schools would oppose to Ammatoans' worldview, especially related to the notion of personhood because one of the agendas of the schooling is to alienate Ammatoans from their tradition and worldview.

It is, however, undoubtedly to argue that Ammatoans' 'animistic' practices are parallel to the Quranic accounts. Ammatoans' commitment to engage with interpersonal relationship could be viewed as the application of the Quranic notion of huquq. In any case, Ammatoans profess to be Muslim and therefore they are Muslim. As a matter of fact, Islam, Talal Asad advocates, is discursive tradition. ${ }^{86}$ Ammatoans' practices are the examples of animistic practices of Islam. The Ammatoan case shows that someone could be an animist and at the same time as a Muslim. Animism (the new version) and Islam are now clear that they are not mutually exclusive but rather complementing to one another.

${ }^{86}$ Quoted in Mahmood, Politics of Piety, p. 115. 


\section{BIBLIOGRAPHY}

Adhan, Syamsurijal, "Islam dan Patuntung di Tanah Toa Kajang: Pergulatan Tiada Akhir", in Hak Minoritas: Dilema Multikulturalisme di Indonesia, ed. by Hikmat Budiman, Jakarta: Interseksi Foundation, 2005.

Ali, Abdullah Yusuf, The Meaning of the Holy Qur'an: New Edition with Revised Translation, Commentary, and Newly Compiled Index, 10th ed., Beltsville: Amana Publications, 2003.

Aminah, Sitti, Nilai-nilai Luhur Budaya Spiritual Masyarakat Amma Toa Kajang, Ujung Pandang: Depdikbud Provinsi Sulawesi Selatan, 1989.

Bird-David, Nurit, “'Animism' Revisited: Personhood, Environment, and Relational Epistemology", Current Antbropology, vol. 40, no. S1, Feb 1999, pp. S67-S91 [doi: 10.1086/200061].

Blackburn, Thomas C. and Kat Anderson (eds.), Before the Wilderness: Environmental Management by Native Californians, Menlo Park, CA: Ballena Press, 1993.

Carrithers, Michael, Steven Collins, and Steven Lukes (eds.), The Category of the Person: Anthropology, Philosophy, History, New York: Cambridge University Press, 1985.

Cense, A.A., "De Patoentoengs in Het Bergland Van Kadjang", manuscript, Koninklijk Instituut voor Tall-, Land- en Volkenkunde collection, 1931.

Chishti, Saadia Khawar Khan, "Fitra: An Islamic Model for Human and the Environment", in Islam and Ecology: A Bestowed Trust, ed. by Richard C. Foltz, Denny Frederick Mathewson, and Azizan Haji Baharuddin, Cambridge: Harvard Divinity School, 2003, pp. 67-84.

Al-Damkhi, Ali Mohamed, "Environmental ethics in Islam: principles, violations, and future perspectives", International Journal of Environmental Studies, vol. 65, no. 1, Feb 2008, pp. 11-31 [doi: 10.1080/00207230701859724].

Dutton, Yasin, "The Environmental Crisis of Our Time: A Muslim Response", in Islam and Ecology: A Bestowed Trust, ed. by Richard C. Foltz, Denny Frederick Mathewson, and Azizan Haji Baharuddin, Cambridge: Harvard Divinity School, 2003.

Foltz, Richard, Animals in Islamic Tradition and Muslim Cultures, Oxford: Oneworld, 2006. 
Foucault, Michel, The Hermeneutics of the Subject: Lectures at the College de France 1981-1982, ed. by François Ewald and Alessandro Fontana, trans. by Graham Burchell, New York: Picador, 2005.

Hallowell, A. Irving, "Ojibwa Ontology, Behavior, and World View", in Teaching from the American Earth: Indian Religion and Philosophy, ed. by T.B. Tedlock, New York: Liveright, 1960, pp. 17-49.

Haq, S. Nomanul, "Islam and Ecology: Toward Retrieval and Construction", in Islam and Ecology: A Bestowed Trust, ed. by Richard C. Foltz, Denny Frederick Mathewson, and Azizan Haji Baharuddin, Cambridge: Harvard Divinity School, 2003.

Llewellyn, Othman Abd-ar-Rahman, "An Islamic Model for Human and the Environment", in Islam and Ecology: A Bestowed Trust, ed. by Richard C. Foltz, Denny Frederick Mathewson, and Azizan Haji Baharuddin, Cambridge: Harvard Divinity School, 2003.

Maarif, Samsul, "Dimensions of Religions Practice: The Ammatoans of Sulawesi, Indonesia", Ph.D. Dissertation, Arizona: Arizona State University, 2012.

Mahmood, Saba, Politics of Piety: The Islamic Revival and the Feminist Subject, Princeton: Princeton University Press, 2005.

McKanzie, Catherine, "Origins of Resistance: The Construction and Continuity of Identity in Tana Towa (Bulukumba, South Sulawesi, Indonesia)", Ph.D. Dissertation, Sydney: Australian National University, 1994.

Morrison, Kenneth, "The Cosmos as Intersubjective: Native American Other-Than-Human Persons", in Indigenous Religions: A Companion, ed. by Graham Harvey, New York: Cassell, 2000.

Muttalib, Abdul, "Arti Positif Sikap Isolasi Masyarakat Kajang”, presented at the Temu Budaya Sulawesi Selatan, Ujungpandang: Kanwil Depdikbud Sulawesi Selatan, 1998.

Nasr, Sayyed Hossein, "Islam, the Contemporary Islamic World, and the Environmental Crisis", in Islam and Ecology: A Bestowed Trust, ed. by Richard C. Foltz, Denny Frederick Mathewson, and Azizan Haji Baharuddin, Cambridge: Harvard Divinity School, 2003.

Ozdemir, Ibrahim, "Toward an Understanding of Environmental Ethics from a Qur'anic Perspective", in Islam and Ecology: A Bestowed Trust, ed. by Denny Frederick Mathewson and Azizan Haji Baharuddin, Cambridge: Harvard Divinity School, 2003. 
Samsul Maarif

Penard, W.A., “'De Patuntung' of South Sulawesi, Malakaji”, Tijdschrift voor Indische Taal-, Land- en Volkenkunde, vol. 55, 1913.

Rahman, Fazlur, “Some Key Ethical Concepts of the Qur'an”, The Journal of Religious Ethics, vol. 11, no. 2, 1983, pp. 170-85.

Renre, Abdullah, Patuntung di Kecamatan Sinjai Barat, Ujung Pandang: Institut Agama Islam Negeri Alauddin, 1978.

Rössler, Martin, "Striving for Modesty: Fundamentals of the religion and social organization of the Makassarese Patuntung", Bijdragen tot de Taal-, Land-en Volkenkunde, vol. 146, no. 2, 1990, pp. 289-324 [doi: 10.1163/22134379-90003220].

Said, Abdul Aziz and Nathan C. Funk, "Peace in Islam: An Ecology of the Spirit", in Islam and Ecology: A Bestowed Trust, ed. by Richard C. Foltz, Frederick Mathewson Denny, and Azizan Haji Baharuddin, Cambridge: Harvard Divinity School, 2003, pp. 155-84.

Sirajuddin, Munirah, Mencermati Makna Pesan di Kajang, Surabaya: Citra Adi Bangsa, 2002.

Usop, K.M., Pasang ri Kajang: Kajian Sistem Nilai di "Benteng Hitam” Amma Toa, Ujung Pandang: Pusat Latihan Penelitian Ilmu-Ilmu Sosial UNHAS, 1978. 